\title{
CITIZENSHIP AND GENDER IN THE PUBLIC LAW CURRICULUM: RECLAIMING POLITICAL STORIES AND CONTEXT†
}

\author{
KIM RUBENSTEIN*
}

When I was asked to transform my paper delivered at the 1995 Feminist Legal Academic Workshop into a Legal Education Review article, I expanded my outline into a slightly more detailed form. In looking at incorporating "feminist material" into the curriculum I concentrated on citizenship in light of my teaching and research interests in constitutional law, administrative law and migration law. As I have recently begun to think of these matters in my teaching, much of my talk looked at options and possibilities; in many ways it was a list of possible material that could be included in public law courses. On its submission for publication, I was tactfully informed that it "was not suitable for publishing ..., as it [was] still very much a conference paper". I was asked to remove the conversational language, and apart from changing the style, I was also asked to give more detailed information about the material that could be included in the public law courses and how that material could be used. I agree with the latter concerns and this article attempts to advance my conference paper. However, the question of style and content "suitable for a law review article" highlights a critical issue which also impacts on this topic. This article proposes that we recognise that there are different ways of imparting information in the written form, and that the conversational piece is a legitimate part of legal scholarship. Moreover, our curriculum should include creative styles of legal expression for our students to accommodate and encourage difference. This will in turn assist us in our feminist concerns about citizenship and the law school curriculum. Furthermore, it is vital that we consider the teaching of material in ways that include the political contexts within which public law exists. Therefore, in changing my conference paper into this article, I am relying to some extent on some of the scholarship of critical theory; in particular, the embracing of subjectivity of perspective and the avowedly political. ${ }^{1}$ Often the method of critical discourse is the narrative, ${ }^{2}$ and I am maintaining the narrative style of my original conference paper, relying upon my own teaching experience. My story is therefore seeking to emphasise the message of the critical movement of being concerned with the stories that highlight the different political issues at play. It seeks to show that many stories are excluded from public law forums because of the way we speak about public law. Part of our role as teachers is to reclaim the stories and the greater political contexts within which citizenship is exercised in public law. Sometimes this means listening to and thinking about legal issues in styles and formats that are not considered publishable by mainstream journals.

\section{CONSTITUTIONAL LAW}

If we are looking for women's experiences in constitutional law we have a difficult task ahead of us. Women "appear rarely as litigants, occasionally as members of Parliament, sometimes as part of the Executive, and virtually never as Judicial decision makers." ${ }^{3}$ In fact, Deborah Cass and I have argued that "unless Australian Constitutional law takes seriously the challenge from women to include them and their interests in the representative process, beginning with the way in which alterations to the Constitution are debated, the constitutionality of the whole system is surely in doubt." ${ }^{\prime 3}$ This is something we must highlight and raise for discussion with our students. ${ }^{5}$

In addition to such an overview, there are some opportunities to highlight the lack of women's voices. For this reason I have valued teaching the case $R v$ Pearson; Ex parte Sipka ${ }^{6}$ (Sipka). Not only does it highlight a lack of concern for those with less power in the community, but the case also highlights how the 
Court was able to both use, and misuse, the setting within which our Constitution was framed in its interpretation of section 41 of the constitution. ${ }^{7}$ The majority decision of Sipka interpreted the guarantee in section 41 as a transitional guarantee only According to them, that guarantee ceased to exist after 12 June 1902, the date on which the Commonwealth Franchise Act came into force. ${ }^{8}$

In this, my third year of teaching the case, I asked a colleague to attend my class in order to provide me with some constructive feedback on my teaching. I outlined the facts to the class as follows.

An election was called in 1983 and four persons who sought enrolment on their own State and Commonwealth electoral rolls were entered on their state rolls, but their entry on the Commonwealth roll was denied, because the rolls had been closed. This gave rise to the question of whether section 41 protected their right to vote in the Commonwealth given they had a right to vote in the State.

A student asked me what had prompted these young people to pursue this matter? Was there any particular context for this action? She was a thoughtful student and I told her this was a very good question, but I would need to follow up the answer for her. I could not remember from my own experience. I was not quite entitled to vote in the 1983 election! Moreover, I had just embarked upon a year travelling overseas before beginning my law degree, so I had not been in Australia when the election was called. The next day my colleague who had been sitting in my class told me that it had occurred to her overnight what the furore had been about in 1983. Malcolm Fraser had announced the calling of an election on 4 February $1983^{9}$ and had closed the polls on that same day at $6 \mathrm{pm}$. Many argued that Fraser had deliberately closed the polls immediately so as to exclude as many young people voting who had turned 18 but had not yet enrolled on the Commonwealth polls. The assumption was that young people were more likely to vote against the Liberal party. The Public Interest Advocacy Centre in Sydney had taken on this case with the support of the NSW Law Foundation to challenge this ostensible manipulation of the voters and the democratic system.

The outline of the facts of the case which had appeared in the judgments of the Court had not given me that particular political context, even though it had methodically explained the timing of the calling of the election and the closing of the polls. Nor was the political context explained by the Court in its review of the material. Was it democratic to close the polls so quickly after announcing the election? Did this distort the validity of the process? Was Justice Murphy correct in his minority judgment that "in issue is the integrity of the Australian democratic electoral system”? ${ }^{10}$

It was the historical story of the Constitutional framing process that the majority relied upon and it is in this context that we can introduce the stories of women and their lack of involvement with the drafting of the Constitution. At Federation, the qualifications of electors of the respective States were not uniform. This was particularly so in relation to the position of women. Only South Australia and Western Australia extended the franchise to women over the age of 21. This struggle for the vote also has other critical issues worthy of consideration in our courses. Many of the early attempts to extend the franchise were limited to women who owned property or were married, and did not always extend to Aboriginal women. ${ }^{11}$ All women were not protected by the franchise, race and class were also at play.

But those women who did have a vote at the time of the Constitutional conventions, did have some influence over the wording of the Constitution. The South Australian women had threatened that if they lost their vote at Federation, they would not support the move to Federation. Their delegates were the people who were involved with the drafting of what became section 41. In order to ensure that those women would be entitled to vote in the Commonwealth elections, section 41 precluded the Commonwealth from legislating to prevent them from voting.

The Sipka case can be taught in many ways. We can highlight the dismal voting system for women that existed at Federation, an issue which questions the very democratic foundation of our Constitutional system. We can emphasise the fight by the South Australian women to protect their existing right to vote, perhaps in the hope that it would have some influence over the Commonwealth fight for women's franchise. We should consider how the partial involvement of some women influenced the formation of our Constitution, and that the lack of a fuller involvement by women limited the value of the Constitution for women. ${ }^{12}$ We have a responsibility to raise these critical issues for the students' consideration to ensure that they are exposed to matters beyond the formal context of legal cases.

We can also use the case to display the limited context within which the majority of the Court was prepared to consider the issues, and how it was not concerned with the other political story of the 1983 
election. ${ }^{13}$ The majority of the Court used the historical story to read down the scope of section 41 ; they claimed that it did not establish a general "right to vote". Because of its version of the story, the Court chose to limit the impact of section 41 until the time that the Commonwealth Franchise Act 1902 came into force. The Court held that if a more general right was upheld it would give the States the power to destroy the Commonwealth's power to create a uniform franchise. The majority was concerned with power as an issue between the States and the Commonwealth; it took no account of the individuals who would be affected. The Court interpreted the successful fight of the South Australian women as one concerned with the protection of State legislative power, more so than the individual rights of women.

Incorporating the historical and political stories more fundamentally in the curriculum will provide a more critical method of teaching and understanding the place of women, as a group disadvantaged in the constitutional legal world. If we are keen to include feminist material in the law school curriculum, this should be so both in terms of our approach to the way we teach the law, and in the focus of our attention to the stories in the cases.

\section{ADMINISTRATIVE LAW}

As public law courses are concerned with the law about the state, we must consider starting these courses with an assessment and critique of the role of the state. In both constitutional and administrative law and also specialist administrative law courses such as migration law, we can present the political context within which law operates. Rules about the state and developed by the state are fundamentally political. Political theorists deal with these issues, and we should consider incorporating their material into the curriculum. ${ }^{14}$ Eva Cox's 1995 Boyer lectures dealt with some of those broader questions, and her lecture "The Companionable State" is an accessible text for undergraduate students to consider these complicated issues. She traces the different views of the state and seeks to defend government and the role of the state in fostering a "truly civil society". ${ }^{15}$ The fact that different political approaches concerning the state have different impacts on individuals and groups within society can be illustrated through the stories of those with less power in the community. How can those individuals best effect change so that the system better addresses their needs? These questions deal with the very heart of our concerns with citizenship. Who is able to participate and who is best protected by our system of law?

Australian Feminist jurisprudence on the state is extensive, and we have much we can draw from in dealing with these questions. Sophie Watson's Playing the State: Australian Feminist interventions ${ }^{16}$ includes different approaches to promoting feminist concerns. The femocrats represent one approach, of working within the system, ${ }^{17}$ but other approaches to "working" the state are also included; examples include the setting up of women's refuges..$^{18}$ Stories of women's experience is fundamental to our teaching of constitutional and administrative law, as one example of how the state impacts upon different groups within the community, and the way the law operates in light of this. ${ }^{19}$

Another challenge ahead of administrative law teachers is in stripping back the principles of administrative law, such as procedural fairness, judicial review, and merits review, and the machinations of administrative law practice to consider their impact on the disadvantaged and less powerful in the community. Margaret Thornton has addressed these issues in the Discrimination law context, which exists within administrative law frameworks. ${ }^{20}$ Most of the administrative law disputes are decided in adjudicative forums which are subject to the criticism levelled against the legal tradition in general, with its foundation of formal equality before the law, which camouflages the practical inequality of experience of those with less power. The current Sex Discrimination Commissioner has challenged the present system as one that "militates against real gains for disadvantaged groups". ${ }^{21}$ This can be drawn out in administrative law by finding cases that reflect the difficulties encountered by women, and those with less power and telling their stories.

\section{MIGRATION LAW}

Political stories abound in migration law, and the concerns of citizenship are central to the subject. I begin my course by asking my students a fundamental political question: Why do nation states have the right to decide who enters their borders? The existence of migration law in itself reflects a political reality 
of the power of domestic sovereignty in the international legal context which can be challenged. ${ }^{22}$

Similarly who are we allowing into Australia? Is the nondiscriminatory policy a reality? Issues of gender arise in this context, and Ruth Fincher, Lois Foster and Rosemary Wilmot highlight the gender inequity in immigration law and the influence of gender on selection policy. ${ }^{23}$ Ruth Fincher has also written about the intersectionality of race, class and gender, and the issues this raises for policy development. The principal question she asked is whether policies that represent women in certain ways can ever be comprehensive enough to apprehend those multiple identities of the people they affect and, therefore, be socially just. In doing this, she uses examples from Australian policies of immigration and multiculturalism. ${ }^{24}$ Her article could be used in any administrative law course.

Migration law revolves around citizenship: non-citizens are subject to the nation state's control regarding entry and departure. Unlawful non-citizens are people who do not hold a valid visa. Because of the centrality of citizenship to the whole system, I spend some time in my course looking more closely at the concept of citizenship itself. Australian citizenship law is confused, unclear and lacking in meaning. ${ }^{25}$ This should be highlighted in order to critique laws that discriminate on the ground of citizenship. ${ }^{26}$ Moreover, the concept of citizenship needs to be analysed in order to determine which groups within the community benefit from the definition of citizenship. There is a lot of feminist material which argues that citizenship privileges males in choosing public activity as the main criteria for good citizenship. ${ }^{27}$ This material could be included in many courses; property, equity, tax, social security and labour law are some examples of where the law is part of the system that disadvantages women. Bringing out women's tales is necessary to such an understanding.

\section{CONCLUSION}

The narrative/conversational style I have used in this article reflects my experiences as a teacher of public law subjects. Public law revolves around citizenship. Our duties as teachers include the highlighting of the tales of those disadvantaged by the legal system, as a process fundamental to our understanding of citizenship. My story about Sipka is just one example. This style of teaching will raise the critical questions for our students so that they consider the social and political values that are part of the dominant legal system. This also means including in our curriculum legal articles that are written in styles other than the traditional law review article.

$\dagger$ I would like to thank my colleagues at The University of Melbourne Law School who participated in a Critical Race Theory seminar, and the seminar leaders, Richard Delgado and Jean Stefancic, for their comments on this paper. I am also grateful for the criticisms and comments of Margaret Thornton. The views expressed, of course, are mine alone.

* Faculty of Law, The University of Melbourne.

(C) 1996. (1995) 6 Legal Educ Rev 241.

1 M Matsuda et al, Words That Wound: Critical Race Theory, Assaultive Speech and the First Amendment (Boulder: Westview Press, 1993). See also R Delgado ed, Critical Race Theory, The Cutting Edge (Philadelphia: Temple University Press, 1995).

2 For a discussion about the different styles of critical scholarship see L Sarmas, Storytelling and the Law: A Case Study of Louth $v$ Diprose (1994) Melb UL Rev 701.

3 D Cass \& K Rubenstein, Representation/s of Women in the Australian Constitutional System (1995) 17 Adel UL Rev 3, at 4. The fact that our Constitution does not have a comprehensive bill of rights nor a singular explicit equality right, has limited the involvement of members of disadvantaged groups in Constitutional litigation.

$4 \quad$ Id at 47.

5 A new casebook due to be published in 1996 looks at theoretical issues and Constitutionalism, and has a section titled Feminism and Constitutionalism. See T Blackshield, G Williams, \& B Fitzgerald, Australian Constitutional Law and Theory (Sydney: Federation Press, 1996) 98-108.

6 (1983) 152 CLR 254.

7 No adult person who has or acquires a right to vote at elections for the numerous House of Parliament of a State shall, while the right continues, be prevented by any law of the Commonwealth from voting at elections for either House of the Parliament of the Commonwealth.

8 See the judgment of Brennan, Deane and Dawson JJ. Blackshield et al, supra note 6, at 280.

9 The date of the election was fixed for 5 March 1983.

10 (1983) 152 CLR 254,265.

11 P Stretton \& C Finnimore, Black Fellow Citizenship: Aborigines and the Commonwealth Franchise (1993) 25 Austl Hist Stud 521.

12 See also H Irving, A Gendered Constitution? Women Federation and Heads of Power (1994) 24 WALR 82.

13 One way of emphasising the political context within which the case arose would be to get some newspaper clippings from the time, and perhaps an account of the tactics considered by the Public Interest Advocacy Centre lawyer who ran the case, subject to issues of solicitor/client privilege.

14 Some examples are C Pateman, The Disorder of Women: Democracy, Feminism and Political Theory (California: Stanford 
University Press, 1989); C Pateman \& M Shanley eds, Feminist Interpretations and Political Theory (Pennsylvania: Penn State University Press, 1991); C Pateman, The Sexual Contract (California: Stanford University Press, 1988); and G Duncan ed, Democratic Theory and Practice (Cambridge: Cambridge University Press, 1985).

15 E Cox, A Truly Civil Society (Sydney: ABC Books, 1995) ch 4, 41.

16 (Sydney: Allen \& Unwin, 1990). Other texts worth looking at are: S Franzway, D Court \& R Connell, Staking a Claim: Feminism, Bureaucracy and the State (Sydney: Allen \& Unwin, 1989); A Yeatman, Bureaucrats, Technocrats, Femocrats: Essays on the Contemporary Australian State (Sydney, Allen \& Unwin, 1990); and M Savage \& A Witz eds, Gender and Bureaucracy (Oxford: Blackwell Publishers, 1992).

17 See H Eisenstein, Femocrats, Official Feminism and the Uses of Power, in S Watson ed, Playing the State: Australian Feminist Interventions (Sydney: Allen \& Unwin, 1990); and M Sawer, Reclaiming Social Liberalism: The Women's Movement and the State (1993) 37 J Austl Stud 1.

18 L McFerren, Interpretation of a Frontline State: Australian Women's Refuges and the State, in S Watson ed, Playing the State: Australian Feminist Interventions (Sydney: Allen \& Unwin, 1990).

19 The experience of indigenous Australians and people from non-English speaking backgrounds is also vital and should be included in the curriculum.

20 See M Thornton. The Liberal Promise: Anti-Discrimination Legislation in Australia (Melbourne: Oxford University Press, 1990).

21 As cited in P Bayne, Natural Justice, Anti-Discrimination Proceedings and the Feminist Critique (1995) 3 Austl J Admin L 5, at 15 where the author looks at the case law and attempts to consider the feminist critique of the adjudicative process, acknowledging that there is not a singular feminist critique. See also Thornton, The Liberal Promise, supra note 20, at ch 6.

22 See K Knop, Re/Statements: Feminism and State Sovereignty in International Law (1993) 3 Transnat'l L \& Contemp Probs 293 and J Nafziger, The General Admission of Aliens under International Law (1983) Am J Int'l L 804.

23 R Fincher, L Foster, \& R Wilmot, Gender Equity in Australian Immigration Policy (Melbourne: Australian Government Printing Service, 1994)

24 R Fincher, Women, immigration and the state: Issues of difference and social justice, in A Edwards \& S Magarey eds, Women in a restructuring Australia: Work and Welfare (Sydney: Allen \& Unwin, 1995).

25 I develop this in K Rubenstein, Citizenship in Australia: Unscrambling its meaning (1995) 20 Melb UL Rev 503.

26 The High Court decision of Cunliffe $v$ The Commonwealth (1994) 182 CLR 272 presents some conflicting views of the Constitutional protection afforded to non-citizens.

27 See M Thornton, Embodying the Citizen, in M Thornton ed, Public and Private: Feminist Legal Debates (Melbourne: Oxford University Press, 1995). There is an extensive discussion relating to citizenship and feminism. See M Dietz, Context is All: Feminism and Theories. of Citizenship (1987) 4/116 Daedalus 1; K Jones, Citizenship in a Woman-Friendly Polity (1990) 15 Signs 781; R Lister, Women, economic dependency and citizenship (1990) 4/19 J Soc Pol'y 445; A Phillips, Citizenship and Feminist Theory, in A Phillips, Democracy and Difference (Cambridge: Polity, 1993); C Pateman, Citizen Male (1992) 137 Austl Left Rev 30; U Vogel, Is Citizenship Gender — Specific?, in A Vogel \& M Moran eds, Frontiers of Citizenship (New York: St Martins Press, 1991); A Yeatman, Beyond Natural Right: the Conditions for Universal Citizenship, in A Yeatman, Postmodern Revisionings of the Political (New York: Routledge, 1994); I Young, Polity and Group Difference: A Critique of the Ideal of Universal Citizenship (1989) 99 Ethics 250. 